\title{
Meat Cutting Machine Shaft Design and Analysis
}

\author{
Cipto Cipto*, Klemens A Rahangmetan, Christian Wely Wullur, Farid Sariman, and Hariyanto Hariyanto \\ Department of Mechanical Engineering, Faculty of Engineering, Universitas Musamus, Merauke 99600, Indonesia
}

\begin{abstract}
This study analyzes the maximum load on the shaft construction with a diameter of $12 \mathrm{~mm}$ and a length of $581 \mathrm{~mm}$. The shaft is designed as a shaft for cutting meat with a capacity of $5 \mathrm{~kg}$. The analysis was performed using the finite element analysis method included in the Autodesk software. According to mathematical calculations, the shaft is considered safe because the value of the admissible tension $\tau \mathrm{a}=7.380$ $\mathrm{kg} / \mathrm{mm} 2$ is greater than the maximum tension $\tau \mathrm{p} 5.62 \mathrm{~kg} / \mathrm{mm} 2$. Based on the simulation results of the test, the shaft experiences a maximum off-stress of $61.89 \mathrm{MPa}$, a maximum displacement of $0.07715 \mathrm{~mm}$, , and a safety factor of $3.34 \mu \mathrm{l}$ so that the shaft is classified as safe for use with a Load capacity of $5 \mathrm{Kg}$
\end{abstract}

Keywords: Rice transport vehicle, Strength analyzed, Finite element analysis

\section{Introduction}

\subsection{Shaft and its function}

The shaft is a machine element that continues the force and rotation. The shaft usually has a diagonal cylindrical shape in which other motor elements are built, such as e.g., B. B. gears, pulleys, flywheels, cranes, bearings and other items. The shaft has the properties of accepting bending, pulling, threading or twisting, which work alone or in combination with one another [1]. The wave capabilities can be analyzed using many methods, e.g., B. through direct tests (field tests) or with the help of the software. The wave function is very important, requires accuracy in the construction, the shaft strength is adjusted to the maximum planned load, the calculation method allows the analysis of the components, in this case the shaft, for their safety when taking loads or their exhaustion limit [2]. The evaluation of the service life of components (shaft) by analyzing the stress / strain experienced can identify component fatigue [3].

\subsection{Calculation of shaft diameter}

When calculating the shaft diameter, the correction factor recommended by ASME must be taken into account. Correction factor due to collisions expressed by $\mathrm{K} \mathrm{t}$. The correction factor for subtle loading is 1.0 , if a light bump or impact occurs then 1.0-1.5 is chosen. If the load is carried with a shock or a large impact, then 1.5-3.0 is chosen. The correction factor found in this study was 1.5 because the raw material (meat) was previously placed in the grinding machine when the machine was not in operation, so that the shaft of the grinding machine suddenly received a large impact. Another factor that must be taken into account when determining the shaft diameter is the bending load $\mathrm{C} \mathrm{b}$ that the shaft can absorb. Therefore, when determining the shaft diameter, add a correction factor for the bend $\mathrm{Cb}$ of 1.2

Then the formula for planning the ds shaft diameter is obtained:

$$
d_{s}=\left[\frac{5,1}{\tau_{a}} K_{t} C_{b} T\right]^{1 / 3}
$$

ds $=$ Planned shaft diameter $(\mathrm{mm})$

$\tau_{\mathrm{a}}=$ Material tensile strength $(\mathrm{kg} / \mathrm{mm}) \mathrm{a} \tau$

$\mathrm{K}_{\mathrm{t}}=$ Correction factor for possible collisions

$\mathrm{C}_{\mathrm{b}}=$ Correction factor for the possibility of bending load.

\subsection{Shaft Power}

The energy is obtained from an electric motor, which is transmitted to the meat grinder shaft via the V-belt. At the time of start-up (meat), a lot of effort may be required because the meat is still intact. After a few moments, the meat is cut into small pieces, so it is necessary to correct the average power required using the correction factor in the planning.

The types of correction factors based on the power to be transmitted according to table

\footnotetext{
* Corresponding author :cipto@unmus.ac.id
} 
Table 1. The types of correction factors are based on the power transmitted [1]

\begin{tabular}{|c|c|}
\hline Transmitted power & $\mathrm{fe}_{\mathrm{e}}$ \\
\hline Average power needed & $1,2-2,0$ \\
Maximum power needed & $0,8-1,2$ \\
Normal power & $1,0-1,5$ \\
\hline
\end{tabular}

In this shaft calculation, the maximum power is taken as the planned power, with the aim that the actual shaft can absorb a large impact torque. The correction factor used is $\mathrm{fc}=1.0$.

$$
P_{d}=N . f_{c}
$$

$\mathrm{P}_{\mathrm{d}} \quad=$ Planned power $(\mathrm{kW})$

$\mathrm{f}_{\mathrm{c}} \quad=$ Correction factor

$\mathrm{N} \quad=$ Normal output motor power output $(\mathrm{kW})$

The determination of the main axis dimensions is calculated based on the torsional load and the possibility of bumps / bumps during the load, when the engine starts. The amount of torque acting on the shaft can be calculated:

$$
T=9,74 \cdot 10^{5} \frac{P_{d}}{n}
$$

$$
\begin{array}{ll}
\mathrm{T} & =\text { Plan torque }(\mathrm{kg} \cdot \mathrm{mm}) \\
\mathrm{P}_{\mathrm{d}} & =\text { Planned power }(\mathrm{kW}) \\
\mathrm{N} & =\text { Rotation }(\mathrm{rpm})
\end{array}
$$

The shaft uses material of the type S50C, for which a tensile strength of $\sigma \mathrm{b}=62 \mathrm{~kg} / \mathrm{mm}^{2}$ is assumed inyour planning. Then the torsional stress of the material can be obtained from the formula:

$$
\bar{\tau}_{a}=\frac{\sigma_{b}}{s f_{1} \cdot s f_{2}}
$$

$\tau_{\mathbf{a}}=$ Shear stress clearance $\left(\mathrm{kg} / \mathrm{mm}^{2}\right)$

$\sigma_{\mathrm{b}} \quad=$ Tensile strength of materials $\left(\mathrm{kg} / \mathrm{mm}^{2}\right)$

$\mathrm{Sf}_{1} \quad=$ Safety factors that depend on the type of material

$\mathrm{Sf}_{2}=$ Safety factors that depend on the shape of the shaft $(1,3-3,0)$

\subsection{Software Autodesk Inventor}

Autodesk Inventor is a CAD program (Computer-Aided Design) with solid three-dimensional modeling functions for the visual creation of 3D prototype objects, the simulation and drawing as well as the documentation of the data [4]. In Inventor, a designer can sketch 2D products and model them in $3 \mathrm{D}$ to proceed with creating a visual prototype or an even more complex simulation [5-7]. Autodesk Inventor, developed by the US software company Autodesk, is CAD software for mechanical 3D design for creating digital $3 \mathrm{D}$ prototypes for product design, visualization and simulation [5].

Structure Analysis on Autodesk Inventor:

a. Stress Analysis
Stress analysis is one of the structural testing tools in Autodesk Inventor that is performed using the concept of finite element analysis (FEA). The way it works is to break an object structure under test into connected finite elements, which are managed by special calculations of the software in order to achieve more precise results $[5,8]$.

b. Frame Analysis

In addition to stress analysis, Autodesk Inventor has another tool for testing the structure, namely frame analysis. The concept of this test is to apply engineering mechanics related to the structure of the truss, beam and frame. Load and assist data entry while the output stress, strain, and displacement graphs are displayed $[5,8]$.

c. Prinsip Superposisi

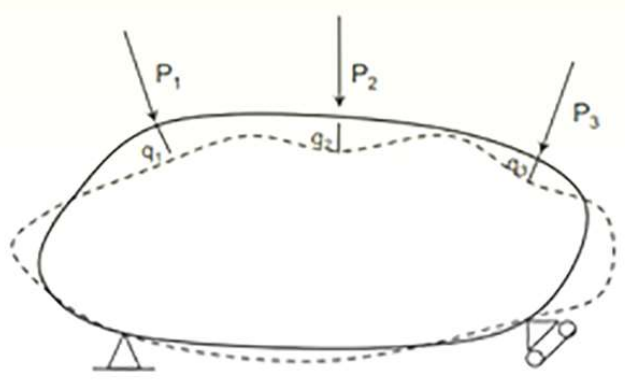

Fig. 1. Displacement on the principle of superposition

For example, an object / structure is subject to three styles $\mathrm{P}_{1}, \mathrm{P}_{2}$ and $\mathrm{P}_{3}$. In the same place and direction with the three forces there was a shift in the components of $\mathrm{q}_{1}, \mathrm{q}_{2}$ and $\mathrm{q}_{3}[9]$.

\section{Material and Method}

\subsection{Shaft Material}

The metal material used to manufacture the shaft is selected according to the standard (JIS G 4501).

Castings with a high carbon content with a content of $\mathrm{C}>0.5 \%$ (construction machinery made of carbon steel S50C) with a tensile strength of $62 \mathrm{~kg} / \mathrm{mm}^{2}$.

\subsection{Shaft Strength Measurement}

The strength measurement in the form of a shear stress test with torque acting on the shaft is carried out in order to determine the maximum rigidity of the shaft. The specified shear stress must not exceed the permissible shear stress so that the shaft does not fail.

The shear stress due to the torque moment acting on the shaft is obtained from:

$$
\tau_{p}=\frac{16 T}{\pi d_{s}^{3}}
$$

\subsection{Loading Conditions}

The shaft load in the meat grinder is as follows. The shaft is supported by two plain bearings and carries two pulleys of different sizes. The geometric shape of the 
shaft and the direction of its loading area in the picture below.

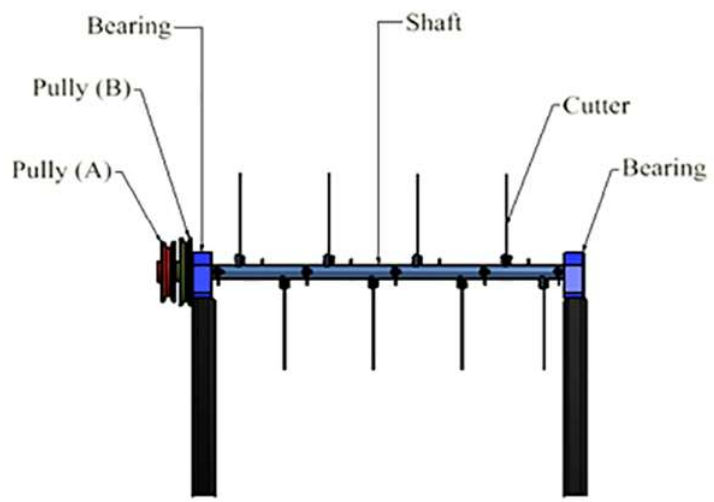

Fig. 2. Meat cutting machine shaft and its components

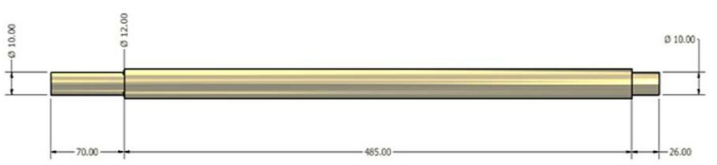

Fig. 3. Shaft geometry and dimensions.

\subsection{The design of the Axis Analysis fund uses}

\section{the Autodesk Inventor 2015 software.}

The design process of sample shaft test design using Autodesk Inventor 2015 software is then carried out in a simulation process with the following steps:

1. Preprocessing, consisting of construction of the motor shaft geometry, determination of the material type, determination of the fixed area, intervention process and determination of the load location and the force magnitude.

2. The process of modeling the shaft geometry with Autodesk Inventor 2015.

3. Create a simulation.

4. Determine the type of material according to the DTA specifications.

5. Static analysis (static analysis), consisting of determining the type of material, determining the hold (fixed), the process of engagement and determining the location of the load and the magnitude of the force.

6. Determination of the boundary conditions and types of loading (boundary conditions).

7. Meshing, in which this geometry is divided into small parts in the form of lines connected by nodes throughout the geometry of objects.

8. Dynamic analysis (modal analysis), which is carried out to find out the personal frequency of the wave in different modes.

9. Solve / execute simulate this process. The data entered in the previous stage is processed to obtain the results of the analysis on the simulation tool.

10. Post-processing is the final process to complete the finite element method. Autodesk Inventor simulation results are displayed in the form of images and total deformation data, as well as calculation results for the maximum stress in the simulation process.

\section{Results and Discussion}

The results of the study were obtained from the results of simulation tests using the Autodesk Inventor software. The force exerted on the shaft is the force of gravity that acts on the shaft and was calculated beforehand. The results obtained are of false stresses, displacements and safety factors.

\subsection{Von misses stress}

Missing Stress is the result of calculating the stressstrain relationship in an object model, the strain obtained from the deformation of the model. The equivalent stress used by the Von Mises method. The representation of the results of the equivalent stress analysis is shown in Figure 4 below.

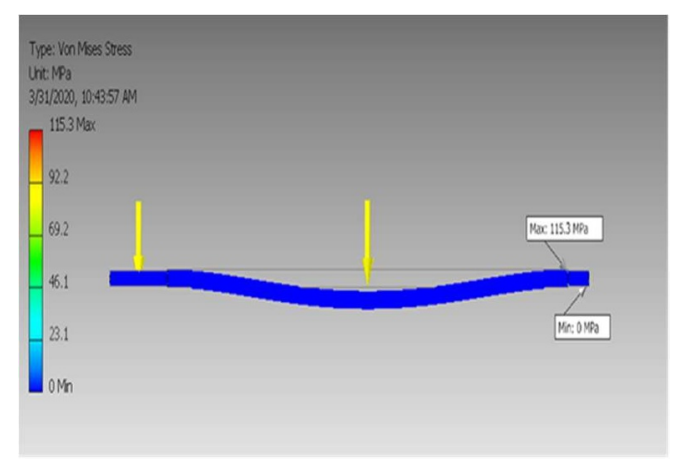

Fig. 4. Von misses stress

The maximum equivalent stress occurs at the end near the fixed constraints at $115.3 \mathrm{MPa}$, then the minimum equivalent stress is $0 \mathrm{MPa}$.

\subsection{Displacement}

Displacement or deformation is the main result of static structural analysis using FEA. The representation of the results of the analysis of the total deformation in the model is shown in Figure 5.

According to the simulation results, the maximum total deformation occurs in the center of the shaft, which is far from the fixation constraints of $0.0106 \mathrm{~mm}$, while the smallest total deformation occurs in the part close to the fixation constraints, which is $0 \mathrm{~mm}$. The representation of the total deformation is shown in Figure 5.

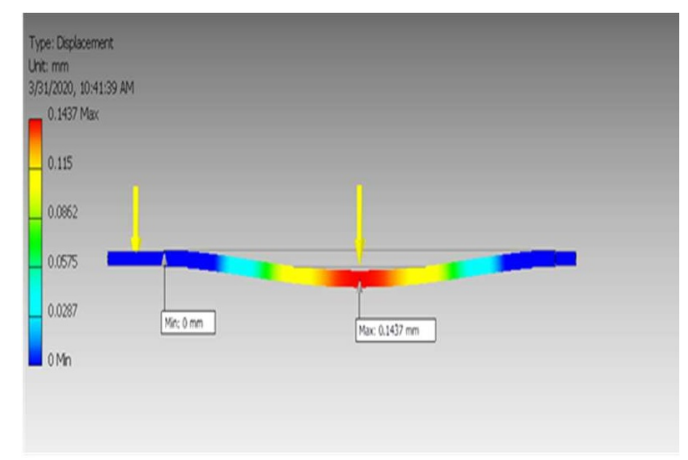


Fig. 5. Displacement

\subsection{Safety Factor}

A factor of safety is one of the important parameters in determining whether a design is feasible or not. The safety factor is the relationship between the permissible material stress and the stress that occurs. The wave is declared safe if the security number is greater than one.

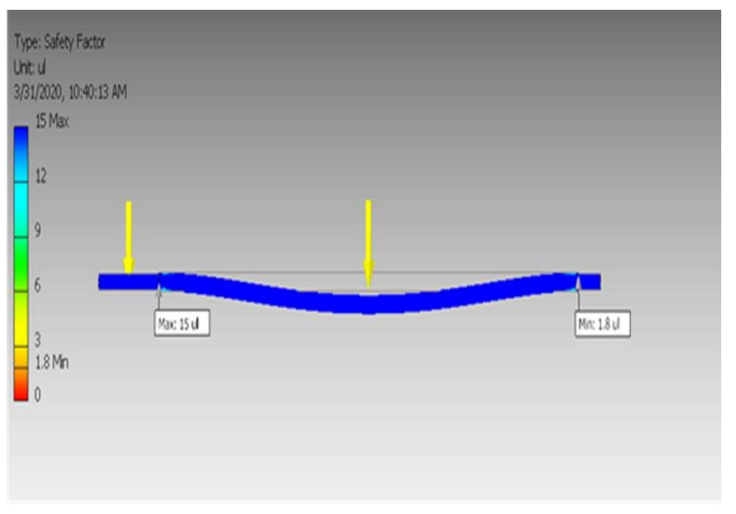

Fig. 6. Safety Factor

Figure 6 shows that when the shaft is loaded with meat weighing $10 \mathrm{~kg}$, the greatest stress occurs at the end of the shaft near the base, with the minimum safety factor $=1.8 \mu 1$

Table 1. Resull Von misses stress

\begin{tabular}{|l|l|l|}
\hline \multirow{2}{*}{ Load } & \multicolumn{2}{|c|}{ Von misses stress } \\
\cline { 2 - 3 } & $\min$ & $\max$ \\
\hline $\mathrm{W}_{1}$ & $0 \mathrm{Mpa}$ & $8,515 \mathrm{Mpa}$ \\
\hline $\mathrm{W}_{2}$ & $0 \mathrm{Mpa}$ & $61,89 \mathrm{Mpa}$ \\
\hline $\mathrm{W}_{3}$ & $0 \mathrm{Mpa}$ & $115,3 \mathrm{Mpa}$ \\
\hline
\end{tabular}

Table 2. Result Displacement

\begin{tabular}{|c|l|l|}
\hline \multirow{2}{*}{ Load } & \multicolumn{2}{|c|}{ Displacement } \\
\cline { 2 - 3 } & $\min$ & $\max$ \\
\hline $\mathrm{W}_{1}$ & $0 \mathrm{~mm}$ & $0,0106 \mathrm{~mm}$ \\
\hline $\mathrm{W}_{2}$ & $0 \mathrm{~mm}$ & $0,07715 \mathrm{~mm}$ \\
\hline $\mathrm{W}_{3}$ & $0 \mathrm{~mm}$ & $0,1437 \mathrm{~mm}$ \\
\hline
\end{tabular}

Table 3. Result Safety Factor

\begin{tabular}{|c|l|c|}
\hline \multirow{2}{*}{ Load } & \multicolumn{2}{|c|}{ Safety Factor } \\
\cline { 2 - 3 } & $\min$ & $\max$ \\
\hline $\mathrm{W}_{1}$ & $15 \mathrm{ul}$ & $15 \mathrm{ul}$ \\
\hline $\mathrm{W}_{2}$ & $3,34 \mathrm{ul}$ & $15 \mathrm{ul}$ \\
\hline $\mathrm{W}_{3}$ & $1,8 \mathrm{ul}$ & $15 \mathrm{ul}$ \\
\hline
\end{tabular}

$\mathrm{W}_{1} \quad=$ Empty shaft weight

$\mathrm{W}_{2} \quad=$ Shaft weight plus $5 \mathrm{~kg}$ of meat

$\mathrm{W}_{3} \quad=$ Shaft weight plus $10 \mathrm{~kg}$ of meat

Table 2 shows that the maximum load is the addition of meat weighing $10 \mathrm{~kg}$, where the maximum safety factor $=15 \mu$ l was obtained, while the minimum safety factor $=1.8 \mu \mathrm{l}$. Based on the safety factor information from Dobrovolsky (machine element) for static loads: 1.25 - 2; dynamic load: 2-3; Impact load 3 5. The shaft belongs to the dynamic load category, so the safety number is at least 2 , so the shaft is not safe to take a maximum load of $10 \mathrm{~kg}$. Shafts can be used safely with a maximum load of $5 \mathrm{~kg}$.

\section{Conclusions}

The conclusions from the above discussion are:

1. The shaft construction of a meat cutting machine made of S50C steel with a maximum tensile strength of $62 \mathrm{~kg} / \mathrm{mm} 2$ can withstand a heavy weight of $5 \mathrm{~kg}$ of meat

2. The more the load is given, the more the value of false stresses and deformations occurs.

3. The construction is considered to be safe, as the specified permissible stress of $8.92 \mathrm{~kg} / \mathrm{mm}^{2}$ is greater than the shear stress of $5.62 \mathrm{~kg} / \mathrm{mm}^{2}$ according to mathematical calculations.

4. The shaft safety factor for a $5 \mathrm{~kg}$ meat load is 3.34 ul. In the safe category, the standard for dynamic loads established by Dobrovolsky (machine element) refers to $2-3$

\section{References}

1. T.A ISKANDAR CHANDRA, Simulasi pembebanan gaya berat pada mill shaft roll shell di pabrik gula sei semayang dengan metode elemen hingga. Medan, (2009).

2. D. C. Lee and C. S. Han, "CAE (computer aided engineering) driven durability model verification for the automotive structure development," Finite Elem. Anal. Des., (2009).

3. F. A. Conle and C. C. Chu, "Fatigue analysis and the local stress-strain approach in complex vehicular structures," Int. J. Fatigue, (1997).

4. B. Setyono and S. Gunawan, "Perancangan Dan Analisis Chassis Mobil Listrik " Semut Abang " Menggunakan Software Autodesk Inventor Pro 2013," Semin. Nas. Sains dan Teknol. Terap. III, (2015).

5. J. M. Saddam Jahidin, "Rancang Bangun 3D Konstruksi Kapal Berbasis Autodesk Inventor untuk Menganalisa Berat Konstruksi," J. Tek. Pomits, vol. 2, no. 1, (2013).

6. A. P. Mahardika, "Introducing Autodesk Inventor," isometriview http://isometriview.wordpress.com/2011/12/08/ intoducing -to-autodesk inventor, (2011). .

7. M. D. Pinem, Analisis Struktur dengan Metode Elemen Hingga (Finite Element Method). Bandung: Rekayasa Sains, (2010).

8. Cipto, K. A. Rahangmetan, F. Sariman, Hariyanto, S. B. Bahar, and M. T. Sapsal, "Stress analysis on the frame of peanut skin peeler using autodesk inventor software," in IOP Conference Series: Earth and Environmental Science, (2019). 
9. B. Setyono, "Perancangan Dan Analisis Kekuatan Frame Sepeda Hibrid 'Trisona' Menggunakan Software Autodesk Inventor," J. IPTEK, vol. 20, no. 2, p. 37, (2016). 